University of Nebraska - Lincoln

DigitalCommons@University of Nebraska - Lincoln

To Improve the Academy

Professional and Organizational Development

Network in Higher Education

1996

Through the Lens of Learning: How Experiencing Difficult Learning
Challenges and Changes Assumptions About Teaching

Stephen Brookfield

Follow this and additional works at: https://digitalcommons.unl.edu/podimproveacad

Part of the Higher Education Administration Commons

Brookfield, Stephen, "Through the Lens of Learning: How Experiencing Difficult Learning Challenges and Changes Assumptions About Teaching" (1996). To Improve the Academy. 352.

https://digitalcommons.unl.edu/podimproveacad/352

This Article is brought to you for free and open access by the Professional and Organizational Development Network in Higher Education at DigitalCommons@University of Nebraska - Lincoln. It has been accepted for inclusion in To Improve the Academy by an authorized administrator of DigitalCommons@University of Nebraska - Lincoln. 
Brookfield, S. (1996). Through the Lens of Learning. In L. Richlin (Ed.), To Improve the Academy, Vol. 15 (pp. 3-15). Stillwater, OK: New Forums Press and the Professional and Organizational Development Network in Higher Education. Key words: Learning, Personal Development, Teaching, Instructional Improvement.

\section{Through the Lens of \\ Learning: How Experiencing Difficult Learning Challenges and Changes Assumptions About Teaching}

\section{Stephen Brookfield}

University of St. Thomas

The author challenges faculty to cast themselves in the role of learners for tasks or subjects which, unlike their areas of expertise, do NOT come easily to them. The purpose is to better understand what it is to experience the struggle shared by many students to grasp new material. The author recounts his own efforts to master a daunting new skill and the many lessons he learned about teaching and learning in the process.

I have a foundational assumption about good teaching that runs as follows: the most important knowledge teachers need to do good work is a knowledge of how students are experiencing learning and perceiving their teachers' actions. To me an awareness of what's happening to students in my classrooms is the first order, framing knowledge I need to teach well. Without this knowledge all the pedagogic skill in the world is irrelevant. I may have a terrific 
command of computer assisted instruction (I don't), be a charismatic lecturer (I'm not), design tests that assess exactly what students have learned (not bad at this), or be able to create lively, democratic discussions (occasionally) - but without knowing what's going on inside my students' heads, I have no way of knowing when, in what way, and with whom these different methods (and others) should be used.

My foundational assumption has two problems embedded at its core. One is the fact that it is impossible to enter another's consciousness and experience in exactly the same way as it is being experienced by the other. Not only is it existentially inconceivable to do this, it is also highly labor intensive to try! How on earth can college teachers be expected to develop an awareness of the multiple ways in which their many students experience their classrooms? Added to this is the difficulty that we teach what we like to learn. Most people end up as teachers of subjects and skills that they were good at as students and that they took pleasure in learning. It would be a masochistic (or very unlucky) teacher who ended up teaching something she hated and had a history of failing to learn. In fact, Andresen (1993), an Australian educator, claims that the reason many people go into teaching is vicariously to reexperience the primary joy they experienced the first time they learned something they loved. By introducing others to the pleasure involved in such learning, they relive the primary joy they themselves experienced as students.

If this is true (and I'm sure that for many of us it is), then this means that most teachers have never been in the same unfortunate position that many of their own students are in - the position of "just not getting it." "I just don't get it" describes the experience of being a stranger in a strange land that settles on many students who can't seem to grasp the essential manoeuvres, the defining operations, of something the professor believes is simple to grasp. If you teach a subject or skill you like and are good at, the chances are that you have never had this sustained experience of struggle, demoralization and total mystification because you just "didn't get it" - because you couldn't understand the simplest organizing principles of a subject or meet the standards for the demonstration of a minimum level of skill competence. Consequently, when you meet students who tell you that they 
don't get your subject, you are perceptually challenged. Helplessly, and with an increasingly surreal sense of frustration, you repeat the manoeuvre again and again, or demonstrate the principle using a variety of examples and analogies, only to be met with the same blank look. Because you have never had this experience of just not getting the subject or skill you teach, you have no autobiographical experiences of struggle on which to draw. You are powerless to help your own students who are in this position because you have never lived through their experience of being blocked and unable to grasp the fundamentals of your discipline.

How can we get ourselves out of this box ? One way is to use different classroom assessment techniques to survey students so that, on a weekly basis, we get some information about what's happening to them. We can then use this information to make more informed pedagogic decisions, to take actions that are grounded in an accurate reading of the emotional and cognitive tenor of our classrooms. In my own teaching I use a weekly, anonymous critical incident questionnaire (the CIQ) to solicit written information from students about the moments during the week's classes in which they were most engaged or distanced, the actions they found most helpful or puzzling, and the ways in which they were taken by surprise. I report this information back to students at the start of each new week and use it to guide much of my practice. A fuller description of this method is contained in Brookfield (1995).

The other way to resolve this problem is to decide that on an annual basis we will deliberately put ourselves in the position of being a student who "just doesn't get it". This means that we will volunteer to learn something that we find intimidating or threatening, in the sure knowledge that what awaits us is a sustained experience of private shaming and public humiliation. As we go through this experiential analog of what many of our own students suffer, we keep a journal of the engaging and distancing moments in our learning. We notice what it is that our teachers do that puts us at our ease or emboldens us, and what it is they do that insults, embarrasses or demeans us. We reflect on these matters in the company of colleagues and then interpret our own practice as teachers from this new vantage point. Seeing our actions through the eyes of a terrified student who has no idea of the 
basic grammar of the learning activity shocks us into a realization of what we should, and should not, do when we meet such learners as a teacher.

\section{Taking the Plunge}

Here is one example of how learning something new and difficult called into critical question several of my causal, prescriptive and even paradigmatic assumptions about good teaching.

It's the mid 1980s. I'm pushing 40, living in Manhattan, and getting flabby. What exercise I get walking along Broadway after dark is conducted amidst car exhausts, requests for money made two or three times per block, and the ever-present danger of ending up under the wheels of a cab driven by an over-zealous (let's be kind and not say maniacal) New York cabbie. This is all extremely stimulating and I never face the problem of boredom that accompanies taking most forms of exercise. However, I've decided that I need to do something safer and healthier, so I decide I'll do some regular swimming, maybe three times a week. The only problem is-I can't swim. So, I've decided to enroll in a swimming class for adult non-swimmers.

Why am I doing this? Well, the woman I am spending a lot of time with suggested I take the class. I protest, saying I don't need it and that I can learn to swim self-directedly, thank you very much. She points out that self-directed learning (where swimming is concerned) isn't getting me very far. I describe to her how I've been working on self-directed swimming since I was in my teens. On each vacation, when the chance arises, I watch people swim in hotel pools, lakes and oceans during the day and observe and remember exactly what it is that they do. Then, under cover of darkness, when everyone else is asleep or eating, I slip out of my room - like some aquatic vampire and make my way to the water, a Bela Lugosi figure with a towel draped around my shoulders rather than a black cape. I slide into the pool, lake or ocean and do my best in near darkness to mimic what I've observed other people do during the bright light of day. Needless to say, I've spent several years floundering (literally, as well as figuratively) in this self-directed learning project. 
When my woman friend hears me describe my autobiography of learning to swim, she gently points out that my "natural"learning style, self-direction, is, in this case, severely dysfunctional for me. (In spite of this humiliatingly penetrating insight, we get married a little later). She says that what I'm really afraid of is looking stupid in front of other people. All this self-direction is a cover for my innate shyness and my arrogant conviction that I can learn anything I want without others assisting me. What I need, she tells me, is to switch from my preferred learning style into a situation where I'm getting some expert instruction. I should study swimming with someone who can break down this extremely complex skill into manageable, but increasingly complex, operations. If this happens, I'm assured, the confidence I will derive from mastering some basic skills will lead me to increase my efforts until, before I know it, I am swimming. I protest that what she's saying is ridiculous, all the while knowing that she's right (a marital dynamic that continues to this day).

\section{Insights So Far}

1. Sometimes the last thing learners need is for their preferred learning style to be affirmed. Agreeing to let people learn only in $a$ way that feels comfortable and familiar can restrict seriously their chance for development. If I had stayed within my own habitual pattern of self-directed swimming I never would have moved beyond the point of staying afloat for a couple of seconds.

2. Self-directed learning, something I have championed unquestioningly for several years, can spring from much darker psychic wellsprings than I had imagined. Instead of representing an admirable resilience and a desire to exercise independent control, it can also betoken a certain arrogance and a fear of public failure.

\section{Meaning for My Practice}

I must think again about my unquestioned belief that good teachers find out the preferred learning styles of their students early on in a course and then spent the rest of the course designing methods and forms of evaluation that connect to these. I realize that this is important to do for some of the time so that students feel affirmed by ways of 
learning that are comfortable and familiar. But it is equally important for me to spend other parts of the course deliberately exposing students to ways of learning that are unfamiliar for them and that will make them uncomfortable, at least initially.

Part of a good educational experience involves broadening the range of learning styles with which students are familiar. No one is likely to be able to spend most of their time learning only in the way they like, so giving students some experience in a range of styles is really in their own best long term interests. From now on I will try to mix methods and evaluative options that strike an equitable balance between affirming students' preferred learning styles and introducing them to alternative ways of learning. My unalloyed reliance on what are thought of as self-directed learning formats (learning contracts, independent studies, individual projects) will have to be balanced with more directive and more collective forms of teaching, learning and evaluation.

\section{The Story Continues ...}

A few weeks later I am in a tiny changing cubicle at a swimming pool. It's the first evening of a class for adult non-swimmers and, while I'm stripping down to my swimming trunks, a number of thoughts are darting through my mind. One is that I hate to show my pale, pimply, naked Englishman's body in public. Its torso and legs are so skinny and underdeveloped and its stomach is so flabby. Another is that I'm probably the only man in America who doesn't know how to swim. I already know I'm the only man in America who doesn't know how to drive (I eventually passed my test when I was 44 after being taught expertly by my wife, a tale that requires a book in itself). Somehow, my lack of aquatic ability embodies my problems dealing with the world of artifacts and the psychomotor domain in general (I have to ask my wife to tell me which is the Phillips screwdriver in the tool box).

A third thought is that it's taking some nerve for me to show up at this class and make a public admission that I don't know how to swim. I think if it's difficult for me to show up at an adult non-swimming class, what must it be like for a non-reader to show up at an adult 
literacy class? What an act of courage that really is! As I step out from my cubicle to the pool side, I look around at the other students in my class. They are all women. Right then and there I know that my suspicion that I was the only man in the whole country who didn't know how to do this was well founded.

Over the next few weeks I splash around in a fairly unconvincing fashion. Matters aren't helped much by having two instructors. One I find much more intimidating than the other. The one I dread meeting is a young man. His athleticism, his muscles, his youth and the aquatic abilities he exhibits have already prejudiced me against him before he has opened his mouth. He seems to bounce rather than walk into the pool area, a pedagogic version of A.A. Milne's Tigger, the kind of muscular jock I hated in high school. Moreover, he looks 16 years old, a fact that causes me to reflect ruefully that when teachers and cops start to look to you like adolescents, you're really hitting mid-life.

Matters are made very difficult by his teaching method, one I would describe as charismatic demonstration. Charismatic demonstration means that he believes that if he shows us how terrifically well he is able to swim, this will inspire in us an uncontrollable desire to match his exemplary performance. On the first night, for example, his first action is to jump in the pool at one end, cut through the water with stunning power, aquatic grace and fluidity and emerge from the water at the other end. As he levitates out of the water, he tells us that we should try to do what he does. He shouts things like "You see how easy it is. That's all there is to it! In ten weeks you'll be doing this too!"

This creates a crashing dissonance, since for me to do anything vaguely resembling what I've just seen is an action so far beyond my comprehension that I feel like throwing in the towel (literally and figuratively). I pull him aside one night and explain that the problem for me - the thing that's really stopping me learn how to swim - is that I hate to put my face in the water. Each time I do this I feel like I'm drowning. The universe becomes a white chlorinated haze, with all my usual reference points totally obscured. I'm reminded of how it used to be when I was having dental treatment in England as a young boy and the dentist would give me gas to knock me out entirely. There was the same sense of being out of control and the inability to stop 
oneself from being submerged by an onrushing smothering force. Putting my face into the swimming pool is as close to a near death experience as I can have while still remaining reasonably sentient.

I ask him if I can do the backstroke (which will at least ensure that my face is out of the water), but he tells me that the crawl stroke is the stroke of choice and that's what real swimmers learn to do. He then says something to me that I forget, but his whole body language conveys to me one unequivocally expressed message: "For God's sake, grow up. For once in your life act like a man."

\section{Insights So Far}

The best learners, people for whom learning a skill comes entirely naturally, often make the worst teachers. This is because they are, in a very real sense, perceptually challenged. They cannot imagine what it must be like to struggle to learn something that comes so naturally to them. Because they have always been so successful in their learning it is impossible for them to empathize with learners' anxieties and blockages. I visualize my swimming instructor as learning to swim through some kind of aquatic Suzuki method whereby he was thrown in the deep end of the pool at three years of age to find out to his surprise that he actually already knew how to swim. Because he didn't experience the terror I feel at putting my head in water, he can't offer any good insights from his own experiences of learning how to swim that might help me keep my fears under control.

Following this line of reasoning, I realize that the best teachers are probably those who have achieved their skill mastery, knowledge and intellectual fluidity only after periods of struggle and anxiety. Because they know what it's like to feel intimidated, and because they have often been convinced that they'll never learn something, they are well placed to help students through their learning difficulties. From now on, when I'm on search committees to appoint teachers, I'll make sure that as I review candidates' C.V.'s, I'll look for academic records that start off relatively undistinguishedly but that improve over time. That will probably indicate that the candidate has a history of struggle as a learner on which she can draw when thinking how to help her own students with their difficulties. 


\section{Meaning for My Practice}

As a teacher I need to find a way of revisiting the terror most people associate with learning something new and difficult. Only if I do this will I be able to help my students with their own problems in learning something that I enjoy teaching. This seems, on the face of it, to be impossible.

I think about ways I could do this. One would be to bring in students from my earlier classes to talk to new students about the emotional difficulties they faced in their own learning. Another would be to find ways of entering my students' emotional worlds, so that I can get some sense of the ways they're reacting to learning. This is the purpose of my classroom critical incident questions described in Brookfield (1995). Maybe the best way would be for me just to keep finding ways of putting myself in the situation of my students; that is, of being a learner in an area of skill or knowledge that is new and intimidating to me. It occurs to me also that in my work with other teachers I should find ways of helping them to do this. This idea eventually becomes the ELICIT faculty development described in Brookfield (1995).

\section{Final Scene ...}

One night about half way through the semester a colleague in the swimming class to whom I am complaining about my fears and lack of progress hands me her goggles and says "Try these on, they might help." I slip them on, put my head in water, and the effect is amazing! At a stroke, the universe has been returned to me! True, the chlorine sting is still in my nose, but the awful white haze has disappeared. I can see the tiling at the bottom of the pool, the lines marking the lanes, even bubbles from my own breathing. I begin my usual attempt at the crawl stroke, trying to coordinate arms, legs and breathing, and after a while I feel my hand hit tiling. "Damn," I think to myself. "I thought I could see where I was going with these goggles, but I must have swum across the pool again, swum a width rather than a length, and all the lap swimmers will be glaring at me for messing up their laps again." 
I raise my head out of the water and I'm astounded at what I see. I'm at the other end of the pool from where I started a couple of minutes before. I've swum a length, not a width ! With this realization I feel a startling jolt of pride, an unalloyed rush of pure happiness. I can't believe it ! I thought I'd never see this moment. I've actually swum a length of a swimming pool without stopping at least once to touch the bottom of the pool and make sure I'm still in my depth, all the while pretending that I'm casually treading water. At some level I knew, or thought I knew, that this day would never come. Now that it's arrived I start to think that maybe I'm not the psychomotor dolt I always thought I was, and that maybe all aspects of the physical world are not totally closed off to me.

Getting tenure, winning awards for books, having a nice round of applause from an audience after a speech, notes of appreciation from students, learning to play the academic game by getting published in prestigious scholarly journals - all these things are nice and affirming, but they pale into visceral insignificance when compared to this moment. By any index, this is a "critical incident" in my autobiography as a learner, a transformative marker event when I looked at myself as a learner in a completely different way and realized a host of new and alternative possibilities for myself.

\section{Final Insights}

1. If it hadn't been for the suggestion of another student that I try on her goggles, I'd still be splashing around in frustration. Her insight and practical suggestion about how to deal with my fears made all the difference in the world to my learning.

2. On almost any scale imaginable by which one could measure aquatic excellence, my performance is pathetic. People 40 years my senior are zooming past and my own actions are an uncoordinated mess of huffing, puffing and unsightly struggling. Yet, in terms of my own estimation of the significance this event has in my history as a learner, this means more than anything that has happened to me for quite a time. So, my subjective assessment of how well I've done probably bears no relation to the instructor's external assessment of my efforts. To him, I'm still a dismally 
uncoordinated wimp who expends many more times the amount of energy than is actually needed to get down to the end of the pool. But external evaluations mean nothing next to my own sense that I've done something really significant. Swimming that length is a learning achievement of intergalactic proportions in terms of my own autobiography.

\section{Meaning for My Practice}

1. I must remember that a student's suggestion that I wear goggles was crucial for my own progress as a learner. I need to remember that the experts on learning are often learners themselves. Within any learning group, students should learn to see each other as resources who can help with learning difficulties. After all, the formally recognized "expert" in the class, the teacher, was of no help whatsoever in getting me past the major blockage to my learning. The person who did most to help me through my anxieties was another learner. I decide I have to find a way of fostering the formation of peer learning groups in my own classes. It's something I believe in, but I need to pay more explicit attention to how I might help these groups form more quickly. It's just been demonstrated to me how crucial a peer's contribution was to my own learning.

2. As an evaluator of my students' learning, I must be careful to remember that what I might judge to be a miniscule, insignificant amount of progress by a student - or even a total lack of movement - may be perceived by that person as a major learning event. Subjective assessments of the meaning of learning to learners may be very different from the objective assessments made by external evaluators. I need to find a way of introducing self-evaluation methods so that students can document - in their own terms - how and what they have learned.

I decide that whenever I can, I will use two evaluative approaches, each of equal importance. I will use my own judgment about the significance of a learner's accomplishments and also the learner's judgment of how much has been learned. This leads me to experiment with participant learning portfolios as an evaluative 
tool in which students demonstrate and document how far they've travelled in terms of their own histories as learners. I also start experimenting with peer evaluations; that is, with students giving narrative evaluative commentary to each other. This is partly to increase the number of evaluative measures and perspectives possible for an act of learning. Partly, too, it's a way of giving students some experience in evaluating learning that will help them when they come to compile their own participant learning portfolios.

\section{Afterword ...}

Joining an adult swimming class is, in the grand scheme of things, a pretty prosaic event. My learning to swim didn't decrease the amount of injustice in the world and it didn't result in any social change. It counted for very little compared to the significant personal learning that people point to as being the most important in their lives. Yet, as a result of this one engagement in an act of learning, I was provoked into challenging and changing some assumptions about my teaching that up to that point I had viewed as axiomatic. Instead of believing that it was my duty to cater consistently to students' preferred learning styles, I now knew that I had to try and strike a balance between affirming these styles and making sure that students were exposed to other ways of learning. No longer would I insist on only self-directed modes of teaching and learning.

Instead of believing that the people who could learn something the best were also the best people to teach it, I now knew that naturally talented learners could be perceptually disabled when it came to understanding the source of students' anxieties about learning. This meant that the best learners sometimes made the worst teachers for students in struggle. Finally, I was granted a new insight into the contradictory, yet internally consistent, interpretations that students and teachers could make of the same learning effort. I knew that what to my eyes were apparently minor actions taken by students could, to them, be events of transformative significance. Knowing this made me a more even handed, empathic evaluator of students and led to my experimenting with forms of self and peer evaluation. 


\section{References}

Andresen, L. (1993). On becoming a maker of teachers: Journey down a long hall of mirrors. In D. Boud, R. Cohen \& D. Walker (Eds.). Using experience for learning Bristol, PA: The Open University.

Brookfield, S.D. (1995). Becoming a critically reflective teacher. San Francisco: JosseyBass

Contact:

Stephen Brookfield

Mail \# CHC 131

University of St. Thomas

2115 Summit Avenue

St. Paul, MN 55105-1096 USA

(612) $962-5382$

(612) $962-5169 \mathrm{FAX}$

Stephen Brookfield began his teaching career in 1970. Since then he has worked in England, Canada, Australia and the United States, teaching adults in a variety of settings. He has written and edited seven books on adult learning, teaching, and critical thinking, and has twice won the World Award for Literature in Adult Education. He currently serves on the editorial boards of educational journals in America, Canada and Australia. After ten years as a professor of higher and adult education at Columbia University in New York, he now holds the title of Distinguished Professor in the Graduate School of Education at the University of St. Thomas in St. Paul, MN. His most recent books include The Skillful Teacher and Becoming a Critically Reflective Teacher. 